\title{
Soundproof Silences? Towards a Sound History of Silence
}

\section{Karsten Lichau}

HCM 7: 840-867

DOI: $10.18352 / \mathrm{hcm} .586$

\begin{abstract}
This article calls for a sound history of silence. Widely neglected within sound-historical research, exploring the manifold sounds of silence not only fills a lacuna in scholarship, but also poses critical challenges to current discussions in the flourishing field of sound history. This theoretical claim is based on empirical case studies from another still unwritten history: the political and cultural history of the minute's silence, a political commemoration ceremony established in the aftermath of World War I. A practice theory approach makes it possible to understand how silence was produced in specific historical contexts through a complex set of cognitive, emotional, logistical, media, physiological, sensorial and kinesthetic practices that engage (or not) with the official call for silence and make it into success or failure. Conceiving of silence as a complex acoustical practice, the article aims to establish silence as a full-fledged topic of research at the centre of sound history and to inspire research on the historical and contemporary interplay between political structures and sensory or bodily practices.
\end{abstract}

Keywords: acoustical practices, Great War commemoration, history of emotions, minute's silence, practice theory, silence, sound history 


\title{
The Call for 'Perfect Stillness'
}

On 7 November I9I9, a call published by King George V in all the major newspapers asked the entire population of the British Empire to fall silent, four days later, at I I o'clock, on occasion of the

\begin{abstract}
first anniversary of the Armistice which stayed the world-wide carnage of the four preceding years and marked the victory of Right and Freedom. I believe that my people in every part of the Empire fervently wish to perpetuate the memory of the Great Deliverance, and of those who have laid down their lives to achieve it. To afford an opportunity for the universal expression of this feeling it is my desire and hope that at the hour when the Armistice came into force, the eleventh hour of the eleventh day of the eleventh month, there may be for the brief space of two minutes, a complete suspension of all our normal activities. During that time ... all work, all sound, and all locomotion should cease, so that, in perfect stillness, the thoughts of every one may be concentrated on reverent remembrance of the Glorious Dead. No elaborate organization appears to be necessary. At a given signal, which can easily be arranged to suit the circumstances of each locality, I believe that we shall all gladly interrupt our business and pleasure, whatever it may be, and unite in this simple service of Silence and Remembrance. ${ }^{\mathrm{I}}$
\end{abstract}

The event that was to take up this call marked the breakthrough of what is today an important element in modern memory cultures. Two men, the Australian journalist George Edward Honey and Sir James Percy FitzPatrick, an author and politician born in South Africa, are often credited with being the 'fathers' of this Two Minutes' Silence, ${ }^{2}$ which was to become (and still is) a central element in annual celebrations of British Armistice Day. During the following years, the minute's silence appeared during commemoration ceremonies of other nations, such as in France and Belgium in I922, and in Poland in $1925 .^{3}$

When this ceremony was also to be introduced into Weimar Germany in I924, Berlin novelist Erdmann Graeser pondered on how to engage with the practices that the forthcoming silence called for:

Is there any familiarity with being seized by standstill and silence? ... Maybe in one or another person something might protest against revealing, 
on demand, the concerns of his heart in a chance location. Usually, one keeps aloof with grief; often the wounds begin to burn by themselves, suddenly, in the silence of the night. How shall we now - amid a motley crowd of total strangers - handle this situation? ${ }^{4}$

Of course, the political contexts of I9I9 Britain and I924 Weimar Germany differed largely from one another, not only because the latter had lost the war, while the former commemorated the 'Glorious dead' who had died for the 'victory of Right and Freedom'. Yet, Graeser's subtle reflections hint at a problem that was common to both British and German participants and that is the topic of my article: the gap between the official 'programme' of political ceremonies - the ideas, intentions and ideologies that it is invested with - and the practices by which it comes into reality: its logistics and bodily performance.

Political, cultural or religious contexts and ceremonial programmes become historically relevant only if they are articulated by individual or collective bodies. George V's claim that such a ceremony of collective silent remembrance needs '[n]o elaborate organization' and that participants would 'all gladly interrupt' their 'business and pleasure' to adopt the called-for behaviour ignores the necessity that bodily gestures and practices actively engage (or not) with the programme, and the agency they are provided with. But how, then, did this articulation and agency work? What were the practices that made the silence and the emotional atmosphere demanded by this modern commemoration ceremony possible? How did these practices (emotional, acoustic, kinaesthetic) interact with each other, and how did they cope with problems? And, finally, how did this translate into political effects: success or failure? In order to answer these questions, I will take a sound-historical and practicetheoretical approach to (the minute's) silence.

\section{Silence and Sound History: Revisiting a 'Strange' Relation}

Two quotes from Jonathan Sterne and Raymond Murray Schafer, two of sound history's most important pioneers, help outline the theoretical problem of this article. They point at the importance of silence within the field of sound history and sound studies, but they also hint 
at the marginal place that silence has been relegated to, and at a reluctance to accept silence as an object of sound-historical research in its own right. In his The Audible Past, Sterne remarked that ' $[\mathrm{t}] \mathrm{he}$ history of sound is at different moments strangely silent'. ${ }^{5}$ Though mindful of silence, he suggests that silence is not a genuine part of sound history, but only invades it from outside 'at different moments', as a 'stranger' ${ }^{6}$ that bewilders the sound historian. And Schafer's emphatic laudation of silence - that '[a]ll research into sound must conclude with silence' 7 - might easily deflect attention away from the question: Why should sound history only conclude with silence? Should not all research into sound also begin with silence? ${ }^{8}$ In what follows, I argue that the seemingly paradoxical notion of establishing the history of silence at the very centre of sound history ${ }^{9}$ goes beyond the pure need to fill a lacuna, and poses critical challenges to some long-guarded assumptions in the history of sound that have recently been put into question.

Attuning (sound) historians' ears to silence(s). In order to establish the fascinating, yet enigmatic phenomenon of silence as a full-fledged field in sound history, some general preliminary considerations are necessary. First of all, any sound history of silence must critically revisit conceptions of silence that reduce it to a pure absence or negation of sound, to the lack or breakdown of communication, or to the muting of (political) voices. For human beings, there is no total absence of sound. ${ }^{\text {Io }}$ While in silence, sounds are reduced in volume, their perception might even be intensified due to the heightened control of sound production and the sharpening of the senses that often go along with silence. At the same time, emphasizing the materiality of silence, we should not forget that silence also means silencing, muting and reducing or eliminating sounds. Therefore, my plea for a sound history of the 'sounds of silence' does not ignore studies on silencing in gender history ${ }^{11}$ or on the muted voices of disabled or deaf communities and individuals, people of colour, underprivileged classes and other subaltern or marginalized social groups. ${ }^{12}$ With Paul Valéry, historians should learn to '[1]isten to this delicate susurration which is silence' as well as to 'hear what is heard when nothing is heard'. ${ }^{13}$ Both the dampening or silencing of sounds and the low-volume acoustics that emerge from it are physically and physiologically manifest, material processes that matter to history. 
My call for a sound history of silence, while focusing on silent sounds and the practices of producing and perceiving them, also emphasizes the contexts they both originate in and interact with. Though one could even argue that the highly complex (cultural) contexts and semiotics of silence have contributed to historians' failure to listen to the sound(s) of silence, sound history, being a field deeply committed to contextualization, must account for the diverse semiotics of silence and the broad range of interpretations and purposes that it allows for. Silence might stand for a multitude of different, sometimes irreconcilable phenomena. In music and the arts, it might serve as a (non-) symbol of the sublime, or of death; it can be an expression of intimate love and a way to discipline or even torture human beings $;{ }^{14}$ it provides a medium for religious mysticism and for rational thinking; and not least, it is a necessary precondition for various aesthetic, scientific and everyday practices, often taken for granted. ${ }^{15}$ Sometimes, however, it can be so significant that it necessitates highly elaborate and very expensive architectural, technological, juridical or administrative measures.

Historical contexts and traditions, as well as the semiotic ambiguity resulting from them, are also at stake in the minute's silence, namely in its peculiar combination of religious and secular, anti-modern and modern elements. For, on the one hand, the silent practices heavily resonated with centuries-old religious gestures established in Abrahamic religions. As a consequence, the minute's silence might be taken as a promise of re-enchanting the secular world, at least for a minute or two. Time and again, personal accounts and reports in print media evoked three key elements in a minute's silence: silence, standstill and a religious-like or 'sacred' aura. These three elements represent the very reverse of 'noise/noise pollution', 'acceleration' and 'disenchantment', which is to say, the central topoi of discourse on the 'crisis of culture' or 'crisis of modernity', as diagnosed in the early twentieth century by thinkers like Ernst Troeltsch, Max Weber, Georg Simmel and Émile Durkheim, who explained the alleged crisis by the loss of religious orientation and processes of secularization and rationalization. On the other hand, the minute's silence also includes some specifically modern elements. As a precisely synchronized silent practice performed in the public sphere, it is enabled only by means of the exact measurement and signal processing of linear time. Drawing on both the semiotics of religious heritage and technical achievements of secular modernity, 
the minute's silence is deeply marked by an ambivalent, if not anachronistic attitude, which exemplifies the instable and dynamic political 'formations of the secular' ${ }^{16}$ and the impossibility of clearly marking off 'the religious' from 'the secular'. ${ }^{17}$

In order to bring to the fore both the micro-historical and macrohistorical dimensions of silence, practice theory provides methods that allow us to conceive of silence neither as an absence or negation of sound, nor as a purely 'positive' sound object, but as a complex of discursive and non-discursive bodily, symbolic and media practices that prepare for, trigger, perform, perceive and comment on silence. While drawing on practice theory himself, Daniel Morat has recently taken issue with some of the problems involved in the way practice theory has been applied to sound history. ${ }^{18}$ Morat aims at

methodically enlarging sound history and opening it for questions of historical performativity. For, up to now, many works on sound history have focused on historical sound objects (in order to inventory the audible) on the one hand, and on the 'extra-acoustical layers of meaning and semantics' tied up to what is heard, on the other ... Yet, this double perspective lacks a third dimension, because speaking of a 'physical reality' or 'physical environment' of sounds and their subsequent interpretation by historical actors locates agency only on the side of perception or appropriation. But prior to the sounds being perceived and given meaning, they are produced. Focusing ... on acoustical practices does not only refer to the practices of perceiving and appropriating sounds, but also and primarily to practices of producing sound ... Such sound acts [Klanghandeln] are an integral part of any historical soundscape and can be analysed as a historically productive factor. ${ }^{19}$

If silence matters to sound history, this is also because, more than any other sound, it reminds us of the importance of 'practices of producing sound'. While it is possible in practice to divide almost all sound practices into their receptive and productive parts - for example when we listen to musical sound objects without producing them - the same is not the case with silence, in which both the production and the reception of sounds coincide with each other. After all, we cannot listen to silence without at the same time also producing it. ${ }^{20}$ This is why I find Morat's insightful suggestions and critique very helpful for exploring 
the sound history of silence. I will enlarge and further develop his concept by introducing the notion of acoustical practices that go beyond single 'sound acts'.

Hi-fi-soundscapes, soundmarks, keynote sounds and signals: producing (a minute's) silence. By closely examining both the complex acoustical framework that official minute's silences (especially in their early period) were usually embedded in and the moment of silence itself, I elaborate on an understanding of silence that neither reduces it to a mere absence of sounds, nor to a purely perceptual or aural phenomenon. The programme by which a minute's silence was usually framed encompassed various types of sounds, among them instrumental music, chorales and hymns, which serve as 'soundmarks'. The latter concept is used to 'refer to a community sound which is unique or possesses qualities which make it specially regarded or noticed by the people in that community'. ${ }^{21}$ This is why soundmarks possess the potential to forge a sense of national community and identity, a key goal of the minute's silence. But they can also serve a purpose that deviates from organizers' desire for national coherence and can provide political agency for expressing and fostering dissent or rifts among political and social groups, which is to say, among the members of the allegedly perfect union of the nation's political body. So, in Scotland or Ireland, the British national anthem was often only performed in an instrumental, low-volume or one-verse-only version, while songs in regional or local dialect were chanted fully and with utmost fervour.

For its part, the silent moment was often framed by mostly short acoustical 'signals', ${ }^{22}$ such as military trumpet calls like 'Last Post', 'The Rouse' or 'Reveille', all widely used in Great Britain; the tunes were intended to capture audiences' attention. Still other signals marked the very beginning and often, though not always, the end of the silent moment, such as ringing bells, firing cannons, rifles, flares and sirens. Both signals and soundmarks provided an acoustical framework that heavily 'resonated with' the silence, giving it an acoustical 'tone' that invested the ceremony with political significance and coherence, but that largely differed from one staging to another: a silence preceded by a national anthem or a military march and signalled by a bugler call 'sounded' different than one introduced by a Christian lament and followed by church bells ringing. 
While this acoustical framework is highly important and 'can be analysed as a historically productive factor', it acoustically centres on the silent moment, which itself comprises manifold sounds. When lapsing into silence, people assembling in a public place, as a crowd, or residing individually or in small groups, produce a whole panoply of low microsounds at the threshold of audibility, such as breathing and digestion, the rustling of fabric, feet shuffling or weeping. Since the very nature of the ceremony dictates that these usually inaudible sounds, originating from inner or outer bodily movements, be controlled and minimized, they are often perceived in a particularly clear and distinct fashion, making the minute's silence into an acoustical panopticon. Because of this disciplinary effect, not only is the perception of these sounds sharpened, but so too is the control of their production. ${ }^{23}$ Beyond the noises of the crowd, there are also non-human sounds like the wind blowing, dogs barking and birds singing, melding with the more distant urban noises of ongoing traffic or industrial production.

However, the 'production' of silence not only involves these microsounds, which make and at the same time defy the intended silence. It also consists of the 'silencing' process, which dampens the acoustical surroundings one is familiar with. The intended break with the noisy background sound of the city, evoked in numerous historical accounts of a minute's silence is reminiscent of Schafer's distinction between a 'lo-fi-soundscape', in which 'individual acoustic signals are obscured in an overdense population of sounds', and a 'hi-fi soundscape ... in which discrete sounds can be heard clearly because of the low ambient noise level'. ${ }^{24}$ In this way, it creates an 'acoustical state of exception'. Hence, the process of 'silencing' is relevant for both the auditory perception and the semantic interpretation of a minute's silence. Even if the acoustical 'din' of the big city is never entirely silenced, not even during a minute's silence, the latter stages a temporary, clear-cut switch from the 'roaring' background noise of modern cities, while at the same time remaining in tension with this noisy sound as to its fundamental 'keynote sound'.25

\section{Silence as Acoustical Practice}

The fragile power of silence: ephemerality, disturbance, emotions. A central concern in establishing sound history was the critical 
examination of the 'audio-visual litany' (Sterne) or the 'great divide theory' (Smith), according to which sounds stand out due to their temporality, their ephemerality and 'presence', their religious dimension, their 'authenticity' and their being imbued with affects. Working with this critical approach, I do not take these features to be timeless and essential qualities or exclusive properties of acoustical or silent practices. Yet, their historical and cultural contingency notwithstanding, these features appear more prominently in sound practices than with visual and textual practices. This makes them a crucial issue for dealing with sounds in general and with the agency of silent practices, in particular. In the following, I want to highlight two of these features. While the first aspect, the ephemerality and fragility inherent to (silent) sounds, is crucial for understanding the close interdependence of the possibly powerful effects of silence and its being prone to failure, the second aspect, the silent minute's affective qualities, involves a vast complex of 'sound acts' and other practices.

Compared to visual and textual practices, (political) sound practices are more susceptible to various kinds of interference. Yet, in theoretical and empirical studies on political staging this issue is too often neglected, due to the overemphasis on the official programmes of such stagings, the initiators' perspectives and the pre-established patterns of interpretation established by mainstream media coverage. This approach often fails to distinguish between the practices 'from above' (conceiving and initiating a ceremony, its intentions and ideological framing), the 'mediating' practices of organization and logistics (planning, preparing, announcing) and the practices 'from below', performing (or not) what the participants' bodies are told to stage (its bodily performance by individual and collective bodies, their emotional and cognitive interpretations). It is the complex interplay between all of these practices that decides upon the success or failure of the whole staging, as well as on its long-term establishment or destabilization as a custom.

Testifying to the fragility of (silent) acoustics, the history of the minute's silence is full of testimonies to wilful interruptions, some of them planned beforehand, and mostly motivated by political dissent. A second type of disturbance is due to bad logistics and poor organization. While the problems caused by the latter are not intentional, they can be just as harmful to the staging as the former. Finally, numerous accounts 
testify to unintentional and more or less 'aleatory' incidents. All three types of disturbances account for the gap between official programmes designed by groups or institutions such as governments, political elites, parties or veterans' organizations and the complex fabric of silent practices, which are interwoven into a set of acoustical, emotional, cognitive, visual, discursive, logistical and media practices.

Empirically grasping the fragility of acoustical stagings, silent or not, demands analyzing them on the level of these practices and foregrounding the importance of the participants' engagement with such stagings. It necessitates accounting for how actors grapple with acoustical fragility as well as their attempts to cope (or not) with disturbances and problems in the performance of such practices. This is also important for understanding what might seem to be a paradox. I would argue that the fragility of acoustical stagings in general and of silent ones in particular accounts for their power and their potential to successfully form participants into a political body, the members of which are not only joined by means of thoughts and discourse, but by sensorial and emotional practices.

So, while a child crying during a minute's silence undoubtedly disturbs the performance, it may nevertheless be perceived as coherent with the overarching political meaning of the staging, particularly its affective dimension. One example of this can be found in a letter that former soldier Bill Grant wrote to his family, in which he describes his impressions on I I November I9I9. 'A child started to cry but was quieted by his mother - but that cry sounded Ioo times louder than ordinary because of the great hush. [W]ho knows but the mother there whether or not the father of that child was represented in that Column of Stone' (this refers to the temporary cenotaph erected in London Whitehall, where the central ceremony took place, though in I9I9 this column was not yet the later stone version, but a wooden structure). ${ }^{26}$ The child's crying, amplified by the surrounding silence, obviously broke the silence, and therefore exposed the silence's fragility. Not only did it interrupt the acoustic unity of the silence; it also distracted the other individuals from participating in the disciplined practice of reverential or mourning devotion. However, by alluding to the possibility that this child might be weeping for having lost its father to the war, Grant's interpretation transforms the weeping child into a 'sound of silence' that might even deepen and foster the event's acoustic-emotional impact on other participants. 
Sounds, emotions, acoustical practices. Grant's anecdote brings us to a second aspect that accounts of the minute's silence often allude to: their emotional dimension. Sound acts, silent or not, reach far beyond mere sound(s). ${ }^{27}$ As we have seen with the weeping child, emotional practices are closely intertwined with practices of producing and perceiving silent sounds, which turn out to be a complex combination of practices involving physiological (crying, listening, immobilizing), cognitive or imaginary (thinking of the possibility of the child's father having died in war) and emotional (the melodramatic sadness or compassion of Grant, the child's fear or mourning) practices.

Monique Scheer, in her seminal outline of a practice theory approach to the history of emotions, emphasized that 'emotional practices' encompass vast complexes of practices (acoustic, affective, discursive, cognitive and other) which are intrinsically woven into each other. ${ }^{28}$ Only by taking them as parts of such sets of practices can we come to grasp their meanings, their agency and their powerful effects:

Access to emotion-as-practice - the bodily act of experience and expres-
sion - in historical sources or ethnographic work is achieved through and
in connection with other doings and sayings on which emotion-as-practice
is dependent and intertwined, such as speaking, gesturing, remembering,
manipulating objects, and perceiving sounds, smells, and spaces. I have
termed these 'doings and sayings' 'emotional practices', which build on
the embodied knowledge of the habituated links that form complexes of
mind/body actions. ${ }^{29}$

This holds true for silence, too: it is perhaps no coincidence that silence and immobility rank high among the 'emotional practices' of interiorization. Thus, 'the imparting of the desired emotional response involves imparting the requisite bodily disposition, for example in the silent, reverent postures and minimal movements that support interiorization'. ${ }^{30}$

I would like to put forward the concept of acoustical practices to account for the 'complexes of mind/body actions' that silence and sound are made of, further developing Morat's emphasis on the historical agency and the productive dimension inherent to 'sound acts', but bringing to the fore that acoustical practices cannot be reduced to single 'acts'. ${ }^{31}$ Acoustical practices are multiple practices, all of them interwoven and interacting with each other, and all of them both produced and perceived. 


\section{Acoustical Practices in the History of the Minute's Silence}

The following case studies from the early years of the minute's silence in Great Britain, France and Germany centre on such acoustical practices by exploring how silence is interwoven into a fabric of practices and how the interplay of these practices make the intentions of organizers and initiators succeed or fail.

Problems and coping strategies in the British Two Minutes' Silence. The British Two Minutes' Silence turned out to be more successful than in most other countries. However, this does not mean that there were no problems with the public and private stagings of silence in Great Britain. Rather, the practices used to cope with different problems turned out to be more successful than elsewhere, as evidenced by a corpus of different texts preparing for, describing and commenting on the experiences during the Two Minutes' Silence. These newspaper articles, personal documents (letters, diary entries) and official reports offer different perspectives on the event.

Of course, as much as the perfect unity of a nation is an illusion, there is no such thing as the 'perfect silence' of the nation, as conjured up by George V. Moreover, we cannot know what individual people or collective political bodies 'really' thought, felt or heard. While the British Two Minutes' Silence was soon to become the paradigm for other countries, British sources also turn out to be paradigmatic for understanding both the fragility and power inherent to this ceremony, as well as the crucial role of acoustical and emotional practices in its performance. So, George V, in his call for silence, was mistaken in believing that the logistics of signalling the very moment when his people were to simultaneously fall into silence would be 'easily arranged' ${ }^{32}$ The allegedly homogeneous sound of silence was not simply achieved by collectively listening. This sound also had to be produced: the population had to fall silent at precisely the same moment, throughout the whole country, at I Ih, o min, o sec.

While synchronization with the colonies and dominions was impossible due to the enormous time differences, it also turned out to be a quite difficult and problematic task even in the British homeland, particularly in big cities and metropoles. During the I920s, maroons were the acoustic devices most commonly used for signalling the beginning of the silence within the confines of the different districts and neighbourhoods. 
These maroons had to be synchronized if the silence was to take place at the same time everywhere. Yet, in the early years of the minute's silence, London's system of locally installed clocks connected to centrally adjusted devices of time measurement was not yet sufficiently built up. ${ }^{33}$ Thus, while the silence had already begun in one town district, maroons or gun fire from neighbouring districts repeatedly disturbed the silence that was supposed to articulate a 'perfect' unity. Town officials faced more and more complaints, and in I924 the use of maroons for signalling the beginning of the silence was forbidden in London. But due to a lack of alternatives, the maroon was back just a year later, in I925. ${ }^{34}$ These difficulties in synchronizing a minute's silence account for the latter's fragile acoustics and remind sound historians that 'prior to the sounds being perceived and given meaning, they are produced'. ${ }^{35}$

Anger, fully interiorized: an unorthodox emotional practice of silence. If we take the complaints reaching the town officials as evidence of the population's engagement with the ceremony, and hence for its success rather than for its failure, they also make clear that the power of silent acoustical practices cannot be explained by sound(s) alone. This becomes evident in the following newspaper article, which discusses the emotional dimension of silent acoustical practices and provides us with an example of a non-habitual emotional practice. Though this text only anticipates the forthcoming feelings, the practice it proposes is highly instructive. On I I November, the Daily Herald - at the time the most important independent left-wing newspaper - published an article calling for readers to participate in the Two Minutes' Silence. The beginning of the article does not stand out from those published in mainstream newspapers:

You are asked to be silent for two minutes to-day, to be silent and to pause in your labours, to remember this day and this hour last year. At I I a.m. a year ago this day the guns that had made the days hideous and the nights hell ceased firing along all the Western front ... And to-day, at the same hour, you are to be silent for two minutes; you are to stand bareheaded wherever you be; you are to remember the Glorious Dead. ${ }^{36}$

Yet, while following the call for silence, the Daily Herald encouraged its readers to perform an emotional practice that differed from the 
official program, adding to the emotional spectrum an affect far from the aims of the organizers. The article did this by drawing up its own list of what was to be remembered, but also of what was likely to be silenced and forgotten:

What will you remember and what will you forget? You will remember, mothers, the gay sons you have lost; wives, you will think of the husbands who went out in the mist of the winter morning - the mist that sent cold chills round the heart - never to come back. And brothers will think of brothers, and friends of friends, all lying dead to-day under a tortured alien soil. But what will you forget? The crime that called these men to battle, or the fond, glorious and tragic delusion under which they went. The war that was to end the war, and that in bitter reality did not? The lies, the hatred, the cruelty, the hypocrisy, the pride; and the agony, the tears of the innocent, the martyrdom of the weak, the hunger of the poor? Make the most of this day of official remembrance. By the sacred memory of those lost to you, swear to yourself that never again, God helping you, shall the peace and happiness of the world fall into the murderous hands of a few cynical old men. ${ }^{37}$

By recalling past feelings and sensations, the unknown author seeks to spark emotion in the present. We can therefore conceive of his text as an 'emotive' that has a descriptive, relational and self-exploratory dimension..$^{38}$ And just like 'sound acts', emotives must be understood as a 'historically productive factor', insofar as they have the ability to 'do things to the world. Emotives are themselves instruments for directly changing, building, hiding, intensifying emotions, instruments that may be more or less successful'. ${ }^{39}$ Clearly, though not expressed directly, the emotions that Daily Herald's invocation wanted to build reached far beyond respect, grief and mourning (the affects intended by the organizers) to encompass rage and hatred. But these affects are detached from the bodily gestures they are usually combined with: gestures that tend towards outward expression by means of external, often agitated facial or bodily movements, words or cries, not to mention aggressive and violent acts. None of these are appropriate or even possible for a participant of a minute's silence, and indeed, the article does not allude to any such visible or acoustic articulation of the anger-andhatred spectrum of emotions. 
Though quite unusual, the promotion of silent and motionless anger is coherent with the "emotional regime' ${ }^{40}$ of interiority and privateness, the origins of which lie in Christianity and which are characteristic of the modern secular self and its isolation from the outer world. ${ }^{4 \mathrm{I}}$ In this case, however, it is remarkable that the Daily Herald recommended this interiorization practice for anger and rage, feelings that one would expect to be either externalized and screamed out or entirely suppressed, while here they are invoked only to be interiorized. ${ }^{42}$ This is a rather difficult and complex task and is perhaps only conceivable under the harsh emotional regime of 'Edwardian stoicism', ${ }^{43}$ which admonished Britons, and not only those from the upper classes, to keep their feelings to themselves and avoid displaying emotions.

Though intended to articulate dissent and protest, such silent acoustical practices undeniably contributed to the 'success' of the minutes' silence, at least as far as an observer might conclude from his or her acoustical and visual perception of such practices of internalized anger. While above, with Grant's weeping child, we saw that emotional practices can compensate for trouble and failure in the acoustical staging of silence, here things work the other way around, with the silent sound allowing for the staging of a more or less homogenized acoustical unity, though participants are affectively deeply divided.

Other countries make even more evident why promoting this peculiar practice was so remarkable and why it highlights once more the importance of taking the production of (silent) sounds into account. In France, and even more so in Germany, groups of people politically close to those addressed by the Daily Herald did not engage in the same acoustical practices when expressing their rage and hatred.

Split-up silence(s): failed synchronization in the French minute's silence. In France, too, the question of how to remember the war and its soldier victims was far from being a matter of political consensus. The controversy focused on the question of what exactly was to be commemorated: Whereas the government (at the time a centre-right 'Bloc national', composed of liberal and conservative parties) had a strong interest in celebrating the 'glorious' victory of the French nation and hence tended to prefer ceremonies that made the triumph of the military (and the state) visible and audible, most of the veterans' organizations fiercely opposed this glorifying approach, which risked obscuring not 
only the misery of dead soldiers, surviving veterans and their relatives, but also what an important part of the anciens combattants deemed to be the stupidity and absurdity of the 'Great War'. ${ }^{4}$

When, in I922, the model for the Jour de l'Armistice was established, it mostly adhered to the veterans' preference for a humble ceremony, free of all glamour, belligerent bluster and politicians' speeches. The veterans wanted the ceremony to "not celebrate war, nor the victory of the institutions' and to 'not be an opportunity for a military review, demonstration of arms, or parade, nor - which is even more original for a republican celebration - for any speech pronounced by the head of state'. ${ }^{45}$ But silence not only prevailed with regard to the 'silencing' of the government. The veterans' striving for a decent, humble and sober form of commemoration also resonated with the minute's silence, which had already proven successful in Britain. It also allowed for a strategic coalition between the Church and the anciens combattants (who otherwise clung to lay anti-clericalism). In consequence, the version of the minute's silence that was implemented in France - modern laicism's most prominent pioneer - was often described in terms of a religious or even specifically Christian event. It invested in the celebration an atmosphere of religious mourning rather than of patriotic glorification. This was also accentuated by the sound signalling the end of the minute's silence: 'The foreheads go up, life resumes, all is finished ... And all the church bells start ringing', ${ }^{4}$

In France, many newspapers reported on the celebration of the Jour de l'Armistice in general, as well as on the minute de silence in particular, in large-format, front-page articles. A number of these read as if the official program, published a few days before, had simply been directly translated into the past tense, adding some trivial and fairly astonishing details and stereotyped descriptions of emotional reactions. To cite only one example: 'Suddenly, a call reverberates: "Ouvrez le ban!" The head of state, the ministers, the officials, and the crowd, the entire crowd, stand immobile. And it's the enormous silence, in which, for a minute, only the glory of the hero was to waft' ${ }^{47}$

Yet, other newspapers describe the performance faltering due to bad logistics and planning, which made the rivalry between the veterans and the state literally reverberate with the 'sounds of silence'. Just like other newspapers, La Croix dwelled on how the President of the Republic, Alexandre Millerand, inspected the troops gathered at the Arc 
de Triomphe. But it also drew attention to an unforeseen interruption of the protocol that others do not mention:

[The] inspection took a bit longer than was planned. For, the cannons' thunder had already sounded, commands for beginning had been given, but the President was still far from the tomb of the unknown soldier. While the enormous crowd, following the command, stood still in the most moving silence, there was a moment of hesitation among the official representatives. Then the second cannon was sounded, and the final command once again made the air vibrate, without the most honorary representatives having paid their reverence to the dead of the Great War, as had been planned. On Monsieur Poincaré's [then prime and foreign minister, K.L.] intervention, some short commands were given. The bugles were blown once again, and for a minute, the president, ministers, generals and legates stood still, while the troops presented their arms. And despite this misunderstanding, it was very moving. At I Iho5, everything was over. ${ }^{48}$

Tellingly, these delicate details are conveyed by a Catholic newspaper noted for its distance towards the government and president. They blame President Millerand, the highest representative of the nation and renowned as a supporter of the Union sacrée, for making the ceremony falter by disturbing the acoustical synchronization of population and political representatives.

In addition to splitting up the silence at the Arc de Triomphe, there was a second problem with acoustic synchronization that further underscores the fragility of silence and its being prone to unintended disturbances and failure because of bad organization and logistical mistakes. Invited to participate in the minute's silence not only at the central ceremony, but also in their neighbourhoods, large parts of Paris's population turned out to be excluded from the silent unity. Though participation was not as strong as it had been in Great Britain, a considerable number of people joined in public spaces, waiting for the signal to announce the beginning of the silence. But especially in quarters not so close to the town centre, many of them waited in vain, as reported in L'Intransigeant: 'The pneumatic clocks show eleven o'clock. Ears are listening, cannon firing is supposed to sound ... But the noise of busses and taxis fills the town ... The clock hands move forward. Waiting, one minute, two minutes ... Nothing', ${ }^{4} 9$ 
Several other articles similarly testify to the failed performance of silence. Obviously, the plan to have only one central signal - cannons that were fired at the Dôme des Invalides - had not been well thought through, since they turned out to be inaudible in the more distant neighbourhoods on account of traffic and other noises. The decentral use of maroons, as had been practiced in London for several years, would have been a better choice: Though they did not reach as far, they were also less prone to being scattered by the wind and interfering noise. And they would have worked out all the more because, since I879, Paris had been equipped with precisely the kind of highly developed system of synchronized pneumatic clocks that London and other British cities lacked.

'It was by far too sad and lacklustre': the fight for adequate emotions. The acoustical practices supposed to perform the allegedly 'perfect' silence ultimately failed to join into a unique sound in France. But what about the emotional practices that might have helped people cope with the acoustical fragility of silence? The subsequent interpretations of the minute de silence engaged in a controversy over which emotions were adequate for commemorating dead soldiers. Here, emotions played an important and active role in negotiating and establishing the Jour de l'Armistice within French memorial culture and the minute's silence as its dramaturgical climax.

The strategic alliance between veterans and the Catholic Church strengthened both the religious dimension in the staging of the minute's silence and its funereal attitude. Unsurprisingly, this was not appreciated by other parts of the population and the more patriotic faction amongst the veterans, especially those who supported the government or had more right-wing convictions:

I would like to repeat also what I already said about this celebration of November I I: It was by far too sad and lacklustre ... There was no joy in the faces. All the passers-by seemed to take down to earth the illusions they had had in 19I8. Paris offered a funeral physiognomy, more or less as it would have offered on November I I had this day been the anniversary of Wilhelm II's triumphant entry into the French capital in front of his troops..$^{50}$

Reactions like this were widespread. They attest to a lack of emotional unity that resonates with both the poorly executed acoustics of the minute's silence and its divided political context. 
If the troubles with producing and performing the acoustical practices of silence in Paris arose mainly from insufficient coordination and bad planning, incidents from several regions and provincial towns reported communists deliberately breaking the silence by shouting or making noise. 'Again, at Amiens, communists have, during the minute of devotion, disturbed "the bourgeois' pleasures" by vociferation. The police arrested the rabble-rousers, who have been released, by the way'. ${ }^{11}$ In the years to come, the Jour de l'Armistice and the communists' provocations during the minute's silence culminated in sometimes violent confrontations between left-wing organizations and their far-right political enemies - a problem that also marred the first and only minute's silence in Weimar Germany.

Songbattle at Königsplatz: the failed minute's silence in Weimar Germany. In Weimar Germany, establishing a commemoration ceremony turned out to be an even more complicated challenge than in France. Edwin Redslob, Weimar Germany's Reichskunstwart ('Imperial Art Protector') finally succeeded in arranging a Gedenkfeier des Deutschen Volkes zu Ehren der Opfer des Weltkriegs (Commemoration by the German People in Honour of the Victims of the World War) on 3 August I924, which was to have a 'two-minutecommemoration pause' as its acoustical and emotional highlight. But several important institutions and groups engaged in memory politics (such as political parties, regional governments, the Christian churches, and the very influential militaristic and right-wing league for the care of German war graves, the Volksbund Deutsche Kriegsgräberfürsorge) disagreed about what was to be remembered and how: the soldiers' bravery or their misery, only German soldiers or all soldiers, the fight for Germany or for the Kaiser, glorification or mourning. Some of the organizations also insisted on their own commemoration days in November (for the churches) and March (for the Volksbund). This added to a general lack of political support for Redslob's commemoration ceremony and left it open to planned political attacks, as reported in the Vossische Zeitung:

The two minutes' commemoration pause in remembrance of the dead had just begun and a profound silence lay suddenly upon the square. This was the moment that a few communist groups among the participants had 
chosen to disturb the ceremony. Pamphlets were thrown in the air, and some agitators tried to start speeches. In most cases, the other participants did not tolerate this, and the police also intervened immediately. There were a few attempts to sing the 'Internationale', but these were countered by dissenting groups singing 'Die Wacht am Rhein' and the 'Flaggenlied' [two emblematic songs of the right-wing movements, K.L.], and finally they came to a poor end when the two-minute commemoration pause was over. $^{52}$

Known as being supportive of the Weimar Republic, the Vossische Zeitung did not emphasize what its report nevertheless makes evident: not only did the attempts to disturb the minute's silence come to 'a poor end', so did the official ceremony itself. Unsurprisingly, the minute's silence would never again be observed in Weimar Germany's official remembrance politics.

Interestingly, this attempt at staging a political community unified by silence heavily resonated with the feelings, practices and perceptions made on occasion of the event that the commemoration ceremony on 3 August referred to: the declaration and outbreak of the First World War and the so-called 'Augusterlebnis'. Strikingly, it is precisely this latter event from which Morat derived his concept of 'sound act'. He argues that singing patriotic songs like 'Heil Dir im Siegerkranze' or 'Die Wacht am Rhein' in public places and streets of big cities played a crucial role in acoustically producing enthusiasm for war, 'not merely as an expression of patriotic feelings', but 'as a means of acoustically affecting oneself and others'. ${ }^{53}$

Yet the sounds of early August I9I4 also comprised other types of acoustical practices. Though the sounds these practices produced were lower in volume, or even silent, their political potential in forging unity and national coherence was perhaps just as powerful as the force of collective singing. In the following quote, Johannes Becher, a leftist writer and later the composer of the GDR's national anthem, describes his 'August experience', the moment before King Ludwig III announced the war to the crowd assembled at Munich's Odeonplatz on 2 August I9I4:

Breathless silence reigned over the place. It was so silent that we perceived the torches' sizzling noise and a child's weeping from another corner of the 
place as stentorian sounds. I held my breath. Everyone held his breath ... One silence seemed to follow upon another. I was amazed how a square crowded with people could be so inanimately silent. ${ }^{54}$

Just like the patriotic singing, the collective silence forged the crowd into a political body unified by both the perception and production of minimized sounds.

The silence staged ten years later, on the occasion of the commemoration of the war dead on 3 August 1924, clearly had a similar goal, though it did not explicitly refer to the I9I4 'August silence' and had a different political and emotional tone. Yet, in I924, at Berlin's Königsplatz, a square crowded with people could not be 'so inanimately silent'. About two million German soldiers and a total of seventeen million people had since died, the war had been lost, and making sense of this slaughter had turned out to be an impossible or at least highly problematic task. So, the memory of the breathless, inanimate silence of I9I4 was drowned out, not least by other sensory experiences that the war had brought with it, introducing societal and political rifts that made any attempt at staging the fiction of a unified national body prone to failure.

Among the layers of experiences that buried the I9I4 'August silence' were various silences: the silence of the trenches, of waiting for days, weeks and months, the silent harkening for the enemy in mine warfare (referred to as the 'mole war'), or the deadly silence of the gas might have all turned silence into a fear-laden, if not traumatic sound for a veteran's ear. But on the home front, too, there was another form of war-related silence, laden with awe and sorrow. When, in I9I7, German documentary films followed the success of the famous Battle of the Somme, showing some footage of dead and wounded soldiers, officials were concerned that some of the scenes might provoke shock or nervous breakdowns, especially among women. Yet many reports wrote that instead of shouting, crying or leaving the cinema in shock, the public reacted by falling silent. We should recall that in the early days of cinema, this was an acoustical practice far from having been established as the general attitude of the viewer. The Berliner Tageblatt, for example, describes a test screening of Unsere Helden an der Somme (Our Heroes on the Somme) as follows: 'Everyone in the audience falls silent, no one thinks of applauding the scenes. But no one is left unmoved'. ${ }^{55}$ 


\section{Conclusion}

The history of the minute's silence helps us get a better understanding of the complex nature of acoustical practices and makes clear why it is important to establish silence at the very centre of sound history. If we want to grasp what is at stake in silent practices, we need to account for both their complex historical (political, cultural, religious) contexts and the equally complex set of discursive and non-discursive practices that engage with (a minute's) silence: cognitive, logistical, media, physiological, sensorial, kinesthetic, etc. Such an approach to acoustical practices can help explain the ambivalent character and the political effects of the minute's silence, which heavily builds on religious tradition, yet also bears secular features; whose ephemerality makes it prone to failure, yet also allows for powerful stagings of an acoustically and emotionally coherent political body; and which works as a disciplinary acoustical panopticon, yet also provides individual and collective agency for subversion and resistance.

\section{Notes}

I George, R.I., 'The Glorious Dead. King's Call to His People. Armistice Day Observance. Two Minutes' Pause from Work, passim, e.g. The Times (7 November 19I9) I2.

2 These narratives of the minute's silence as an 'invented tradition' (Hobsbawm) stemming from clearly defined 'fatherly' inventor(s) ignore previous initiatives for the interruption of traffic and/or business and silent standstills. For instance, in February I9I9, some people in the United States called for a minute's silence in memory of President Theodore Roosevelt, who had died on 6 January of that year, though it was ultimately not carried through. Earlier precursory forms of (minute's) silences were observed on the occasion of King Edward VII's burial (20 May I9Io), on I3 February I9I2 in the Portuguese Senate (for the deceased Brazilian diplomat José Maria da Silva Paranhos Júnior, Barão do Rio Branco), and in the April I9I 2 commemorations of the victims of the Titanic. However, these ceremonies varied in length from several minutes to two hours, and did not yet, as the November I I 'Two Minutes' Pause from Work', involve nationwide coordination and synchronization. 
3 After the Second World War, the minutes' silence was adopted by political cultures as divergent as the Soviet Union and Israel. At the same time, the minute's silence partly transcended the frame of national commemoration politics and entered into other memorial cultures: it started being used in local and institutional ceremonies, as well as on a transnational level; for example, on the occasion of Princess Diana's funeral, in the days after 9/I I, and after the recent terrorist attacks in Paris.

4 Erdmann Graeser, 'Stille und Stillstand. Die Zwei-Minuten-Gedenkpause', Vossische Zeitung (3 August 1924) 5. Here and throughout, translations from German and French into English are mine, if not otherwise indicated.

5 Jonathan Sterne, The Audible Past: Cultural Origins of Sound Reproduction (Durham, 2003), I3.

6 Tellingly, the quote does not end here, but notes two more 'strangers' to sound history, namely visuality and its being gory: 'The history of sound is at different moments strangely silent, strangely gory, strangely visual' (Sterne, The Audible Past, I3).

7 Raymond M. Schafer, The Soundscape: Our Sonic Environment and the Tuning of the World (Rochester VT, I994 [1977]), I 2.

8 Schafer not only relegates silence to the end of 'all research into sound'. His considerations on silence are laden with an esoteric tone and appear in contrast to or even detached from the rest of his book (cf. Schafer, The Soundscape, Chapter 19). The same is true when the chapter refers to Barry Truax's account of the minute's silence he attended on a 4 May commemoration in Utrecht. Strangely enough, for a pioneer in exploring sound objects and soundscapes, he largely dwells on his subjective perception of the silence as 'oppressive', as a 'strange and nervous calm', 'an electric moment' or 'a slow unison vibration' (Ibid., 255-6), but his purely metaphorical account is void of the sounds characteristic of a minute's silence that we will encounter in this article.

9 A sound history of silence does not have to start from scratch. Beyond Sterne's and Schafer's reflections, it can also build upon other works, like Emily A. Thompson's path-breaking The Soundscape of Modernity: Architectural Acoustics and the Culture of Listening in America, I900I 933 (Cambridge MA, 2004 [2002]) or Alain Corbin's A History of Silence: From the Renaissance to the Present Day (Cambridge, 2018 [2016]). However, when Thompson explores the new acoustics established in early twentieth century, she mainly focuses on noise and noise abatement and does not systematically reflect on the place silence (as opposed to noise) 
takes within the new acoustics of the early twentieth century, which is striving for a 'clear, controlled, signal-like sound ... [that] was perceived to demonstrate man's technical mastery over his physical environment' (Thompson, The Soundscape, 3-4). And while Alain Corbin's Village Bells, Sound and Meaning in the Nineteenth-century French Countryside (New York, I998) still provides an unsurpassed model for listening to the complex contexts and practices that sounds come out of and interact with, his Histoire $d u$ silence is primarily a literary sound history of silence, lacking the broader social and cultural frame that many of his other studies so compellingly interweave with an analysis of the senses.

Io This is the place where almost every text on silence cannot refrain from citing Cage's account of his visit to an anechoic chamber in Harvard's laboratories. Yet, his allegedly 'innocent' experience of universal silence is far less 'innocent' than often supposed, but was rather based on a good deal of 'silencing', as Douglas Kahn, 'John Cage: Silence and Silencing', The Musical Quarterly 8I:4 (I997), 556-98 has argued.

I I Cf. Tillie Olsen, Silences (New York, I978); Adrienne Rich, On Lies, Secrets, and Silence: Selected Prose, 1966-1978 (New York, I979).

I 2 Rather, it would be an important task to harken for the sounds of these mutings and silencings, the technological and media practices that enable or counter them, and to learn how they might have been listened to, though this task might be very difficult, if not impossible, due to the non-existence of relevant archives (cf. on dealing with archival silences in the history of trans-Atlantic slavery Saidiya Hartman's work, e.g. 'Venus in Two Acts', Small Axe I 2:2 (2008) I-I4).

I3 Paul Valéry, 'The Heard', in: Collected Works. Volume 2. Poems in the Rough, translated by Hilary Corke (Princeton, I969), i66.

I4 Cf. Morag Josephine Grant, 'Pathways to Music Torture', Transposition 4 (2014) (http://transposition.revues.org/494, accessed 5 October 2017).

I5 Establishing a sound history of silence also means grappling with some methodological problems that sound history in general is confronted with, some of them being even more accentuated in the case of silence than with other sounds, as for example the question of suitable sources. While sound recordings are not available for large historical periods, or only in poor quality, we lack recordings of silence even from times when mechanical or electric devices for sound recording were available, but expensive. And even then, when recording devices became more affordable and easier to handle - as was the case with magnetic tapes - silence was often cut out 
from recordings, perceived as something taken for granted and deemed unworthy of being archived. And a sound archive of silence-snippets probably only exists in literary fiction (cf. Heinrich Böll, Doktor Murkes gesammeltes Schweigen und andere Satiren (Cologne, I958)).

I6 Talal Asad, Formations of the Secular: Christianity, Islam, Modernity (Stanford, 2003).

I7 '[T]he secular marks a relational dynamic more than an identity' and 'directs us less toward a determinant set of embodied dispositions than to a distinct mode of power, one that mobilizes the productive tension between religious and secular to generate new practices through a process of internal self-differentiation. The boundaries of our categories religious and secular do not preexist this process but are continuously determined and reciprocally redefined within it.' (Charles Hirschkind, 'Is there a Secular Body?', Cultural Anthropology 26:4 (20 I I), 64 I-3).

I8 Morat, 'Der Sound der Heimatfront. Klanghandeln im Berlin des Ersten Weltkrieges', Historische Anthropologie 22:3 (2014), 350-63, at 352.

I9 Ibid., 35I-2; Morat derives this term from Christian Jansen's 'Musikhandlung'.

20 Arguing against 'the commonplace view that silence is the space of forgetting and speech the realm of remembrance', and conceiving of silence as a socially constructed space that is actively produced by 'a set of cultural practices', Jay Winter also emphasized the production of silence. See Jay Winter, 'Representations of War and the Social Construction of Silence', Elena v. Baraban et al. (eds), Fighting Words and Images: Representing War across the Disciplines (Toronto, 2012), 27-45, at 29. Yet, his interest lying primarily with silence as a phenomenon of memory or communication, his reflections do not include a soundhistorical approach in its own right.

2I Schafer, The Soundscape, 274.

22 Ibid., Io.

23 Due to this disciplinary aspect inherent to silence, it is perhaps not a surprise that the history of education has offered one of the most advanced takes against the inclination 'to understand silence as the mere absence of sound or the mere opposite of sounds and language' (Pieter Verstraete and Josephine Hoegaerts, 'Educational Soundscapes: Tuning in to Sounds and Silences in the History of Education', Paedagogica Historica 53:5 (2017), 49I-7, at 493). In their subtle exploration of the 'educational soundscape', Verstraete and Hoegaerts emphasize that 'silence is something that needs 
to be actively produced and thus cannot be reduced to a mere natural phenomenon' (Ibid., 493). Yet, their claim to do so by 'explor[ing] the aural - consisting of both silence and sound', and to 'demonstrate that what we hear and what we cannot hear is never neutral but always shaped through the sociocultural context of time' (Ibid., 496) locates the production of silence in the ear (and brain), mainly. But the dichotomy of sounds and silences needs to be questioned from the entire spectrum of acoustical practices, not only the aural ones.

24 Schafer, The Soundscape, 43, my emphasis.

25 'In music, keynote identifies the key or tonality of a particular composition. It provides the fundamental tone around which the composition may modulate but from which other tonalities take on a special relationship. In soundscape studies, keynote sounds are those which are heard by a particular society continuously or frequently enough to form a background against which other sounds are perceived ... Often keynote sounds are not consciously perceived, but they act as conditioning agents in the perception of other sound signals.' (Ibid., 272) One could even argue that silence itself might have been taken for a keynote sound, if not of whole societies, at least of an important group within post-WWI-societies: the veterans. For instance, Axel Volmar, 'In Storms of Steel: The Soundscape of World War I and its Impact on Auditory Media Culture during the Weimar Period', Daniel Morat (ed.), Sounds of Modern History: Auditory Cultures in Igth and 20th Century Europe (New York, 20I4), 227-55, argues that the shift in the auditory culture of the I920s was not only due to 'the process of mechanization and mediatization' and 'specifically on the city as the primary area of that shift' (Ibid., 227), but also to different auditory experiences (among them silence) introduced during the war by new weaponry, tactics and media technologies.

26 Grant, cited in: Adrian Gregory, The Silence of Memory. Armistice Day, I919-1946 (Oxford, I994), I5.

27 Jonathan Sterne, too, emphasized this when arguing for a cultural history of sound 'perceptible only through its exteriors' (Sterne, The Audible Past, I3).

28 Monique Scheer, 'Are Emotions a Kind of Practice (and Is That What Makes Them Have a History)? A Bourdieuian Approach to Understanding Emotion', History and Theory. Studies in the Philosophy of History 5I:2 (20I2), I93-220.

29 Ibid., 209. 
30 Ibid., 2 I6.

3I This is what Morat's translation of his own concept of 'Klanghandeln' into 'sound act' - cutting the German term off from its practice theory origins - suggests. Cf. in this special issue Daniel Morat, 'The Sound of a New Era: On the Transformation of Auditory and Urban Experience in the Long Fin de Siècle, I880-I930', International Journal for History, Culture and Modernity (20I9), 59I-60I.

32 George, Glorious Dead, 12.

33 Peter Galison, Einsteins Uhren, Poincarés Karten. Die Arbeit an der Ordnung der Zeit (Frankfurt am Main 2003).

34 Adrian Gregory, Silence of Memory, 42.

35 Morat, 'Der Sound der Heimatfront', 352.

36 Daily Herald ( I November i9i9) I.

37 Ibid.

38 Cf. William M. Reddy, The Navigation of Feeling. A Framework for the History of Emotions (Cambridge, 200 I), 96-I I I.

39 Ibid., I05.

40 Ibid., I 24-6.

4I On the influence of Protestantism in the establishment of bourgeois interiority, see Bettina Hitzer and Monique Scheer, 'Unholy Feelings: Questioning Evangelical Emotions in Wilhelmine Germany', German History 32:3 (2014), 37 I-92.

42 On distinctions between interiorized 'feelings' and exteriorized 'affects' and the ideologies around them, see Monique Scheer, 'Topographies of Emotion', in: Ute Frevert et al. (eds), Emotional Lexicons. Continuity and Change in the Vocabulary of Feeling I70O-200O (New York, 20I4), 32-6I. On the history of hate and its locations in the body, see Birgitte Johansen, 'Locating Hatred: On the Materiality of Emotions', Emotion, Space and Society I6 (20 I5), 48-55; on the history of anger and American ideas about eliminating it, Carol Z. Stearns and Peter N. Stearns, The Struggle for Emotional Control in America's History (Chicago, I986).

43 See Hera Cook, 'Emotion, Body, Sexuality, and Sex Education in Edwardian England', The Historical Journal 55:2 (2012), 475-95.

44 On this controversy see Antoine Prost, Les anciens combattants et la société française. I9I4-I939 (Paris, I977); Rémi Dalisson, I I Novembre. Du souvenir à la mémoire (Paris, 20I3).

45 Dalisson, II Novembre, 49. 
46 J. L. 'Le quatrième anniversaire de la victoire', L'Écho de Paris (I2 November 1922) I. On bells as cultural-acoustic devices for creating community and social adherence in France and the secularist implications of that history, see Corbin, Village Bells.

47 Le Matin (I2 November I922) 4.

48 La Croix (I2/I3 November I922) 2.

49 L'Intransigeant (I 2 November I922) 3.

50 Le Petit Journal ( 2 November I922) I.

5I Le Figaro (I 2 November I922) 2.

52 Vossische Zeitung (4 August I924) 4.

53 Morat, 'Der Sound der Heimatfront', 355.

54 Cited in Süddeutsche Zeitung (20 February 2008) 48.

55 Berliner Tageblatt und Handels-Zeitung (20 January I9I7) 3.

\section{About the Author}

Karsten Lichau is a researcher at the Center for the History of Emotions at the Max Planck Institute for Human Development in Berlin. His research interests include the historical anthropology of the body and the senses, with a special focus on sound history and the history of emotions. He has published Menschengesichte. Max Picards literarische Physiognomik (Akademie Verlag/De Gruyter, 20I4), on the social and cultural history of the face, and, more recently, on the role of sound, emotion and religion in staging politics. His current book project focuses on the cultural and political history of the Minute's Silence in Great Britain, France and Germany. E-mail: lichau@mpib-berlin.mpg.de 